\title{
A Specific Role for NR2A-Containing NMDA Receptors in the Maintenance of Parvalbumin and GAD67 Immunoreactivity in Cultured Interneurons
}

\author{
Jefferson W. Kinney, Christopher N. Davis, Iustin Tabarean, Bruno Conti, Tamas Bartfai, and M. Margarita Behrens \\ The Harold L. Dorris Neurological Research Center, Molecular and Integrative Neurosciences Department, The Scripps Research Institute, La Jolla, \\ California 92037
}

\begin{abstract}
Several lines of evidence suggest that a hypoglutamatergic condition may induce a phenotypic loss of cortical parvalbumin (PV)-positive GABAergic interneurons, such as that observed in brain tissue of schizophrenic subjects. However, it is not known whether the loss of PV interneurons is a consequence of the hypoglutamatergic condition or a secondary aspect of the disease. We characterized the signaling and subunit expression of NMDA receptors in cultured cortical PV interneurons and determined whether a hypoglutamatergic condition, created by direct application of sublethal concentrations of ketamine or subunit-selective NMDA receptor antagonists, can affect the expression of the GABAergic markers as observed in vivo. Real-time PCR performed on mRNA isolated from single neurons showed that PV interneurons present a fivefold higher NR2A/NR2B ratio than pyramidal neurons. Brief, nontoxic, exposure to NMDA led to an increase in ERK1/2 (extracellular signal-regulated kinase 1/2) and cAMP response element-binding protein phosphorylation in PV interneurons, and this increase was blocked by the NR2A-selective antagonist NVP-AAM077. Application of the nonselective NMDA receptor antagonist ketamine, at sublethal concentrations, induced a time and dose-dependent decrease in parvalbumin and GAD67 immunoreactivity specifically in PV interneurons. These effects were reversible and were also observed with the NR2A-selective antagonist, whereas the NR2B-selective antagonist Ro-25-6981 only partially reduced GAD67 immunoreactivity. Coexposure to the calcium channel opener BayK, or the group I metabotropic glutamate receptor agonist DHPG $[(R S)$-3,5-dihydroxyphenylglycine] attenuated the decrease in GAD67 and parvalbumin induced by the NMDA receptor antagonists. These results suggest that the activity of NR2Acontaining NMDA receptors play a pivotal role in the maintenance of the GABAergic function of PV interneurons.
\end{abstract}

Key words: NMDA receptors; parvalbumin; hypoglutamatergic; GABAergic; schizophrenia; mGluR5

\section{Introduction}

Convergent evidence provides support for the theory that a diminished cortical inhibitory drive may contribute to schizophrenic symptoms. Expression of the $67 \mathrm{kDa}$ form of glutamic acid decarboxylase 67 (GAD67), the enzyme responsible for most of GABA synthesis in the brain, and expression of the calciumbinding protein parvalbumin (PV) were shown to be consistently decreased in the prefrontal cortex of schizophrenic subjects (Asada et al., 1996; Mirnics et al., 2000; Reynolds et al., 2001; Hashimoto et al., 2003; Torrey et al., 2005). This reduction occurred in the PV-positive subset of interneurons, a key GABAergic system responsible for the control of cortical output (Lewis et al., 2005).

Subchronic and chronic treatment of rats with the NMDA receptor antagonists phencyclidine (PCP) (Cochran et al., 2002,

\footnotetext{
Received July 28, 2005; revised Dec. 19, 2005; accepted Dec. 21, 2005.

This work was supported by a Helen Dorris Schizophrenia fellowship (J.W.K.), the National Alliance for Research on Schizophrenia and Depression (M.M.B.), and The Harold L. Dorris endowment (T.B.).

Correspondence should be addressed to M. Margarita Behrens, Division of Geriatrics, Department of Medicine, University of California San Diego, Stein Clinical Research Building, Room 126, La Jolla, CA 92093. E-mail: mbehrens@ucsd.edu.

DOI:10.1523/JNEUROSCI.4722-05.2006

Copyright $\odot 2006$ Society for Neuroscience $\quad 0270-6474 / 06 / 261604-12 \$ 15.00 / 0$
}

2003) or the related compound ketamine (Keilhoff et al., 2004) produced a similar decrease in GAD67 and PV mRNAs, providing a molecular basis for the propsychotic effects of NMDA receptor antagonists (Javitt and Zukin, 1991; Olney and Farber, 1995; Newcomer and Krystal, 2001). However, it is not known whether the NMDA receptors present in the subpopulation of PV interneurons play any significant role in the resulting loss of the GABAergic phenotype in these interneurons after treatment with NMDA receptor antagonists.

The function and signaling of NMDA receptors in the PV subpopulation of interneurons is poorly understood. The absence of the main calcium transducers present in principal neurons (i.e., CaMKII and calcineurin), together with evidence showing that NMDA receptor subunits are expressed at very low levels in PV interneurons (Nyiri et al., 2003), led to the belief that these interneurons would not be able to transduce the calcium signal resulting from the opening of NMDA receptors (Freund, 2003). However, single-cell reverse transcription (RT)-PCR demonstrated the presence of mRNAs coding for NMDA receptor subunits in PV interneurons, and application of NMDA induced dendritic calcium transients in these interneurons, suggesting that NMDA receptors participate in their basal synaptic activation (Monyer et al., 1994; Cauli et al., 1997; Goldberg et al., 2003). 
Here, using a primary cortical-neuronal culture system, we characterized the subunit expression and signaling of NMDA receptors in the PV interneuronal population and analyzed the effects of selective and nonselective NMDA receptor antagonists on the expression of PV and GAD67. We found that PV interneurons express higher levels of NR2A subunits than those found in pyramidal neurons. Brief exposure to NMDA induced the activation of the ERK ${ }^{\mathrm{MAPK}}$ (extracellular signal-regulated kinase mitogen-activated protein kinase) pathway and the phosphorylation of cAMP response element-binding protein (CREB). These responses were preferentially attenuated by the NR2A selective antagonist NVP-AAM077 and less effectively by the NR2B selective antagonist Ro-25-6981.

When exposed to sublethal concentrations of ketamine, there was a significant decrease in PV and GAD67 immunoreactivity specifically in PV-positive interneurons. These effects were also observed with the selective NR2A antagonist NVP-AAM077, whereas the NR2B-selective antagonist Ro-25-6981 only partially reduced GAD67 expression. Increasing intracellular calcium by coexposure with the calcium channel opener BayK or the group I metabotropic glutamate receptor agonist $(R S)$ 3,5-dihydroxyphenylglycine (DHPG) attenuated the decrease in GAD67 and PV.

\section{Materials and Methods}

Neuronal-glial cocultures. Cortical neuronal cultures were prepared from fetal [embryonic day 14 (E14) to E15] Swiss Webster mice as described previously (Rose et al., 1993). Briefly, cortices were dissected from the rest of the brain, placed in $5 \mathrm{ml}$ of growth media, which consists of media stock (MS; Eagle's Minimal Essential Media minus glutamine) with the addition of $20 \mathrm{~mm}$ glucose, $26.2 \mathrm{~mm} \mathrm{NaHCO}_{3}, 2 \mathrm{~mm}$ glutamine, $5 \%$ fetal calf serum, and $5 \%$ horse serum. The tissue was then triturated using a 5 $\mathrm{ml}$ pipette, and cell suspensions were diluted to 0.15 cortices $/ \mathrm{ml}$ and plated onto poly-lysine-coated coverslips. After 9-12 d in culture [9-12 $\mathrm{d}$ in vitro (DIV9-12)] or when glia has reached confluency, proliferation was halted by the addition of $10 \mu \mathrm{m}$ cytosine arabinoside (AraC) for $48 \mathrm{~h}$. Cultures were fed biweekly with growth media (MS with 10\% horse serum) and used for experiments at DIV21-23.

Glial cultures. Cortical glial cultures used for the growth of dissociated neuronal cultures (see below) were prepared from postnatal day 1 (P1) to P3 Swiss Webster mouse brain essentially as described by Goslin et al. (1998). Briefly, whole mouse forebrains were dissected in HBSS and digested in $0.025 \%$ trypsin and $0.1 \%$ DNase for 15 min and then passed through a $70 \mu \mathrm{m}$ nylon mesh (Falcon, Franklin Lakes, NJ). After trypsin inactivation, dissociated cells were centrifuged and plated in glial media (MS with the addition of $20 \mathrm{~mm}$ glucose, $26.2 \mathrm{~mm} \mathrm{NaHCO}_{3}, 2 \mathrm{~mm}$ glutamine, $10 \%$ fetal calf serum, and $10 \%$ horse serum and $100 \mu \mathrm{g} / \mathrm{ml}$ penicillin/streptomycin) on T75 flasks (Falcon-Primaria) and allowed to grow to near confluency. Glia was then lifted and plated on poly-D-lysine $(10 \mu \mathrm{M})$-coated 12 -well plates and grown in glial media until 50\% confluency, when the media was changed to MS:N2.1 (see below). Glial plates were used after 1 week in this media for development of dissociated neuronal cultures.

Dissociated neuronal cultures. For confocal imaging studies, cortical neurons were cultured at low density from the same E14-E15 dissections described above, following a slightly modified procedure from that described by Goslin et al. (1998). Briefly, glass coverslips (Carolina Bioscience, Burlington, NC), to which paraffin feet were added, were coated with poly-L-lysine overnight and preincubated in MS/N2.1 media [MS plus $1 \times$ N2.1 supplements (Invitrogen, San Diego, CA), 2\% horse serum, $2 \mathrm{~mm}$ L-glutamine, $1 \mathrm{~mm}$ pyruvate, and $12 \mathrm{~mm}$ glucose] for 1 week before use. Cortical cells then were plated at a density of $5400 \mathrm{cells} / \mathrm{cm}^{2}$ on the "feeted-coverslips" and allowed to attach for $24 \mathrm{~h}$ before being flipped over onto the pre-established glial 12-well plates that had been kept in MS/N2.1 media for a week. Cytosine arabinoside (5 $\mu \mathrm{M})$ was immediately added to halt the grown of non-neuronal cells in the cover- slips. These cocultures were maintained in MS/N2.1 media for $21 \mathrm{~d}$. Under these conditions, most neurons develop the characteristic morphology of cortical pyramidal cells. Immunostaining with $\alpha$ CaMKII antibodies and GAD67 antibodies confirmed that $80-90 \%$ of the population is pyramidal neurons and $10-20 \%$ is GABAergic neurons.

Electrophysiological recordings. Standard tight seal recording techniques were used with a patch-clamp amplifier (Axopatch 200B; Molecular Devices, Union City, CA). Cortical neurons cultured on glass coverslips were placed in a perfusion chamber containing external solution. Once in whole-cell configuration, the cell was "clamped" at a holding potential of -70 or $-75 \mathrm{mV}$ by continuous current injection. Depolarizing current steps (20-200 pA, $500 \mathrm{~ms}$ duration) were applied to elicit action potentials and determine the spiking pattern of the neuron as described previously (Cauli et al., 1997). The recordings were filtered at 5 $\mathrm{kHz}$ and then digitized using a Digidata $1320 \mathrm{~A}$ interface and the pClamp8 software package (Molecular Devices). The external recording solution was composed of the following (in $\mathrm{mm}$ ): $155 \mathrm{NaCl}, 3.5 \mathrm{KCl}, 2$ $\mathrm{CaCl}_{2}, 1.5 \mathrm{MgSO}_{4}, 10$ glucose, 10 HEPES, pH 7.4 (osmolarity was $300-$ $305 \mathrm{mOsm}$ ). The pipette solution was composed of the following (in $\mathrm{mm}$ ): $130 \mathrm{~K}$-gluconate, $10 \mathrm{KCl}, 10 \mathrm{HEPES}, 2 \mathrm{MgCl}_{2}, 0.5 \mathrm{EGTA}$, pH 7.4. The temperature of the external solution was controlled with a HCC$100 \mathrm{~A}$ heating/cooling bath temperature controller (Dagan, Minneapolis, $\mathrm{MN}$ ) a temperature controller equipped with a Peltier element. The temperature during the recordings was $36-37^{\circ} \mathrm{C}$.

Culture treatments. For NMDA signaling, neuronal cultures developed for $21 \mathrm{~d}$ on coverslips were transferred to HEPES-controlled salt solution (HCSS) containing $1 \mu \mathrm{M}$ tetrodotoxin for at least $2 \mathrm{~h}$ to prevent synaptic activity and then exposed to NMDA $(20 \mu \mathrm{M})$ for the indicated times in the absence or presence of the nonselective NMDA receptor antagonist (+)-5-methyl-10,11-dihydro-5H-dibenzo [a,d] cyclohepten-5,10-imine maleate (MK-801; $5 \mu \mathrm{M})$ or the recently described subunit-selective NMDA receptor antagonist NVP-AAM077 (0.5 $\mu \mathrm{M}$ NR2A-selective; $\mathrm{IC}_{50}, 12 \mathrm{~nm}$ ) (Auberson et al., 2002; Berberich et al., 2005) (a kind gift from Dr. Yves Auberson, Novartis, Basel, Switzerland) or to Ro-25-6981 $(0.5 \mu \mathrm{M})\left(\mathrm{NR} 2 \mathrm{~B}\right.$-selective, $\left.\mathrm{IC}_{50}, 9 \mathrm{nM}\right)$ (Fischer et al., 1997). After treatment, coverslips were immediately fixed in $4 \%$ paraformaldehyde and processed for double or triple immunocytochemistry.

NMDA receptor antagonist treatments. At DIV21, dissociated or cocultured neurons were exposed to varying concentrations of the nonselective NMDA receptor antagonist ketamine or the subunit-selective antagonists NVP-AAM077 and Ro-24-6981 for $24 \mathrm{~h}$. After treatment, the coverslips were fixed in $4 \%$ paraformaldehyde and processed for double immunocytochemistry using anti-GAD67 and anti-parvalbumin antibodies, followed by AlexaFluor-conjugated secondary antibodies (see below).

Immunocytochemistry and confocal imaging. Coverslips containing neurons were washed by immersion in PBS and fixed in ice-cold $4 \%$ paraformaldehyde for $30 \mathrm{~min}$. The coverslips were then incubated for 10 min at room temperature in PBS containing $0.25 \%$ Triton X-100. Nonspecific sites were blocked by incubation in PBS containing 10\% normal goat or horse serum. For double immunostaining, the coverslips were incubated in $2 \%$ normal goat serum containing a dilution of either a mouse monoclonal antibody against parvalbumin (1:4000; Sigma, St. Louis, MO) or a dilution of a rabbit polyclonal antibody against the same protein (1:7000; Swant, Bellinzona, Switzerland), and a dilution of a rabbit polyclonal or mouse monoclonal antibodies against $\alpha$ calcium calmodulin-dependent protein kinase II ( $\alpha$ CaMKII) (ABR), against calbindin or calretinin (Sigma), against GAD67, glutamate receptor 1 (GluR1), GluR2,3, metabotropic GluR1 (mGluR1), or mGluR5 (Chemicon, Temecula, CA) or against NR2A and NR2B (Invitrogen; Upstate Biotechnology, Lake Placid, NY; Santa Cruz Biotechnology, Santa Cruz, $\mathrm{CA}$ ) for $1-2 \mathrm{~h}$ at $37^{\circ} \mathrm{C}$. Specific binding was detected by incubation for 45 min at room temperature with secondary antibodies conjugated to AlexaFluor dyes (594, red; 488, green; Invitrogen). Images were collected on a Delta Vision Optical Sectioning microscope consisting of an Olympus (Tokyo, Japan) IX-70 microscope. A photometrics CH 350 cooled CCD camera and a high-precision motorized XYZ stage were used to acquire multiple consecutive optical sections at a $0.2 \mu \mathrm{m}$ interval for each of the 
fluorescent probes. An Olympus oil immersion $60 \times$ objective was used to collect the images.

All antibodies used in this study have been shown to be suitable for immunocytochemical studies (Snell et al., 1996; Ouyang et al., 1997; Huang et al., 2001; Francis and Deneris, 2002; Barraud et al., 2005; Irintchev et al., 2005).

Fluorescence quantification. The settings of the confocal microscope were maintained constant for each series of experiments so that the resulting images could be analyzed by densitometry and the timedependent changes in fluorescence compared and expressed as a percentage of untreated conditions. For cell imaging, each coverslip was scanned to obtain 30-40 PV-positive neurons ( $\sim 26-30$ images captured per coverslip per condition). Each image analyzed consists of a stack of 160.2 $\mu \mathrm{m} Z$-stage images taken from the base of the neurons and across $3.2 \mu \mathrm{m}$ depth. Neurons in the images were then analyzed for their median green and red fluorescence content using Adobe Photoshop Histogram algorithm (Adobe Systems, San Jose, CA). Backgrounds were defined as the fluorescence intensity in non-neuronal fields and subtracted from the values obtained for each neuron. Values for fluorescence intensity were then calculated as a percentage of control (no treatment) and expressed as means \pm SEM. Each experiment was performed in duplicate (two coverslips from the same dissection per condition), and each experiment was performed at least three times on cells obtained from different dissections.

Analysis of neuronal death. Neuronal death after NMDA receptor antagonist exposures was assessed by propidium iodide (PI) staining (Invitrogen) as described previously (Gottron et al., 1997). Briefly, coverslips were treated with varying $(0.005-2.5 \mu \mathrm{M})$ concentrations of ketamine, NVP-AAM077, or Ro-28-6981 for $24 \mathrm{~h}$, washed in MS, and incubated in this media with the addition of $5 \mu \mathrm{g} / \mathrm{ml}$ PI for $60 \mathrm{~min}$. Incorporated PI was quantified using a fluorescence plate reader (SpectraMax, GeminisXS; Molecular Devices). Percentage of neuronal death was calculated by comparison to a sister culture that was treated with 300 $\mu \mathrm{M}$ NMDA for the same time period and considered $100 \%$ neuronal death. For the quantification of apoptotic neuronal death, coverslips were washed in PBS after $24 \mathrm{~h}$ of drug treatment and processed for double immunocytochemistry using anti-parvalbumin, or anti- $\alpha$ CaMKII, and anti-caspase- 3 antibodies. Percentage of neuronal death was calculated for each neuronal population by counting double-immunostained neurons and expressed as a percentage of the untreated control. Invariably, we found a low percentage, $\sim 8 \%$, of $\alpha \mathrm{CaMKII} /$ caspase- 3 doublepositive neurons but no parvalbumin/capase- 3 double-positive cells. We found increased neuronal death by both methods when applying ketamine at $>2.0 \mu \mathrm{M}$ and NVP-AAM077 or Ro-25-6981 at $>1.5 \mu \mathrm{M}$.

Single-cell mRNA linear amplification. Coverslips containing neurons grown in coculture conditions were fixed in ice-cold $4 \%$ paraformaldehyde in PBS as described above and processed for single-cell mRNA amplification (Kacharmina et al., 1999). After fixation, the coverslips were incubated for $2 \mathrm{~h}$ at $37^{\circ} \mathrm{C}$ in a solution containing $2 \%$ normal goat serum in PBS and monoclonal mouse primary antibody directed against parvalbumin (1:2000 dilution; Sigma) or against $\alpha$ CaMKII (1:300; Affinity Bioreagents, Golden, CO), followed by incubation with secondary antibody from Elite Vectastain ABC (Vector Laboratories, Burlingame, $\mathrm{CA}$ ) following instructions provided with the kit. The coverslips were then prepared for in situ transcription as described below.

In situ transcription. Coverslips were allowed to hybridize with amplification primer in a humidified chamber overnight in 50\% formamide, $5 \times$ SSC, and oligo (dT)-T7 primer (AAACGACGGCCAGTGAATTGTAATACGACTCACTATAGGCGC $(\mathrm{T})_{24}$ at a final concentration of 1 $\mathrm{ng} / \mu \mathrm{l}$. In situ transcription was performed for $90 \mathrm{~min}$ at $37^{\circ} \mathrm{C}$ in in situ transcription reaction mix (50 mM Tris- $\mathrm{HCl}, \mathrm{pH} 8.3,6 \mathrm{mM} \mathrm{MgCl}_{2}, 120$ $\mathrm{mm} \mathrm{KCl}$, in DEPC-treated $\mathrm{H}_{2} \mathrm{O}$ ) containing $7 \mathrm{~mm}$ DTT, $250 \mu \mathrm{M} 4 \mathrm{dNTP}$, $0.12 \mathrm{U} / \mu \mathrm{l}$ RNasin, and $1 \mu \mathrm{l}$ of reverse transcriptase/100 $\mu \mathrm{l}$ of mix (Seikagaku America, Tokyo, Japan). After aspiration of single cells with a microelectrode, the second strand cDNA synthesis and dialysis were performed as described previously (Kacharmina et al., 1999). After dialysis, the single-cell samples were recovered for assessment of antisense RNA (aRNA) population size by using $2 \mu$ l of the dialyzed sample and T7 RNA polymerase ( $1000 \mathrm{U} / \mu \mathrm{l}$; Epicenter Technologies, Madison, WI). The ma- terial was then incubated for a maximum of $4 \mathrm{~h}$ at $37^{\circ} \mathrm{C}$ followed by analysis of aRNA population size distribution via a $1 \%$ agarose RNA denaturing gel. The rest of the aRNA product was processed for a second round of cDNA synthesis, which was performed following the same protocol, except that random primers were used for the first-strand DNA synthesis. The cDNA products were then used for real-time PCR (see below).

Real-time PCR. Quantitative PCR was performed using a Roche LightCycler equipment and LightCycler-Fast Start DNA Master SYBR Green I mix (Roche Products, Welwyn Garden City, UK). Reaction volumes of $20 \mu \mathrm{l}$ were used with $0.5 \mu \mathrm{m}$ primers and $2 \mathrm{mM} \mathrm{MgCl}_{2}$. Specific primers were designed based on the published sequences of mouse glyceraldehyde-3-phosphate dehydrogenase (GAPDH) (primers: forward, $5^{\prime}$-gaacatcatccctgcctctactgg- $3^{\prime}$; reverse, $5^{\prime}$-tccaccaccctgttgctgta- $3^{\prime}$ ) as reference together with parvalbumin (primers: forward, GCAAGATTGGGGTTGAAGAA; reverse, GTGTCCGATTGGTACAGCCT), $\alpha$ CaMKII (primers: forward, ATGCTCCGTCCAAATACCCTCC; reverse, GCAGTGGTCATTCAAGTTCACAGC), GAD67 (primers: forward, CATGGCGGCTCGGTACAAAGTA; reverse, AACAGTCGTGCCTGCGGTTGC), NR2A (primers: forward, GCCTGAGAATGTGGACTTCC; reverse, TTCTGTGACCAGTCCTGC), and NR2B (primers: forward, GCATTTGCCACAATGAGAAGAA; reverse, CACAGTCATAGAGCCCATCAA). Purified PCR products obtained from cDNA made from total forebrain mRNA were cloned into TOPO-TA cloning vector (Invitrogen). After sequencing, the identified clones were used to prepare standard curves for quantification in real-time PCR. Amplified targets in real-time PCR were identified by comparison of their melting profile to that obtained for the standard. The results were normalized by the expression levels of the reference gene, GAPDH, which was quantified simultaneously with the target gene. Analysis is performed by the second derivative method. Amplification conditions are as follows: $95^{\circ}$, $1 \mathrm{~s} ; 58^{\circ}, 10 \mathrm{~s} ; 72^{\circ}, 30 \mathrm{~s}$; for 40 cycles.

Statistical analysis. For normalization, fluorescence values obtained for each cell in the different set of experiments was divided by the mean fluorescence of their corresponding control. Each set of experiment had its own control. Statistical analysis was performed for the normalized values across all same-condition experiments using the one-way ANOVA analysis in SigmaStat software, followed by Tukey's test of all pairwise multiple comparisons procedures. Thus, unless otherwise stated, all $F$ values and degrees of freedom given are for the group.

Materials. Unless otherwise stated, all reagents were from Sigma, except for BayK and DHPG, which were from Tocris Cookson (Bristol, UK).

\section{Results}

\section{Parvalbumin expression in primary cortical cultures}

Primary cortical neuronal cultures are widely used for the study of neurotransmission, neurodegeneration, and neurodevelopment. Here, we used this well established primary culture system to characterize the population of PV interneurons. In this culture system, $>80 \%$ of the cells are pyramidal neurons, as determined by the expression of $\alpha$ CaMKII (Fig. 1, bottom), and GABAergic interneurons represent $\sim 10-20 \%$ of the population, as determined by expression of GAD67 (data not shown). Double immunocytochemical analysis of the interneuronal population in culture showed the presence of nonoverlapping subpopulations expressing the calcium-binding proteins parvalbumin, calretinin, and calbindin (Fig. 1, top and middle), as described in cortical slices (Kawaguchi and Kubota, 1993; Cauli et al., 1997).

Cortical neurons in culture developed current patterns similar to those described for the interneuronal population in cortical slices (Kawaguchi and Kubota, 1993; Cauli et al., 1997) (Fig. 2A). The expression of PV in cortical neuronal cultures followed a similar developmentally regulated pattern as that described in vivo for rodents and primates (de Lecea et al., 1995; Philpot et al., 1997; Erickson and Lewis, 2002), appearing after 8-9 d in vitro (DIV8-9) when the PV-positive subpopulation represented 8\% of the GABAergic population (as determined by double immu- 

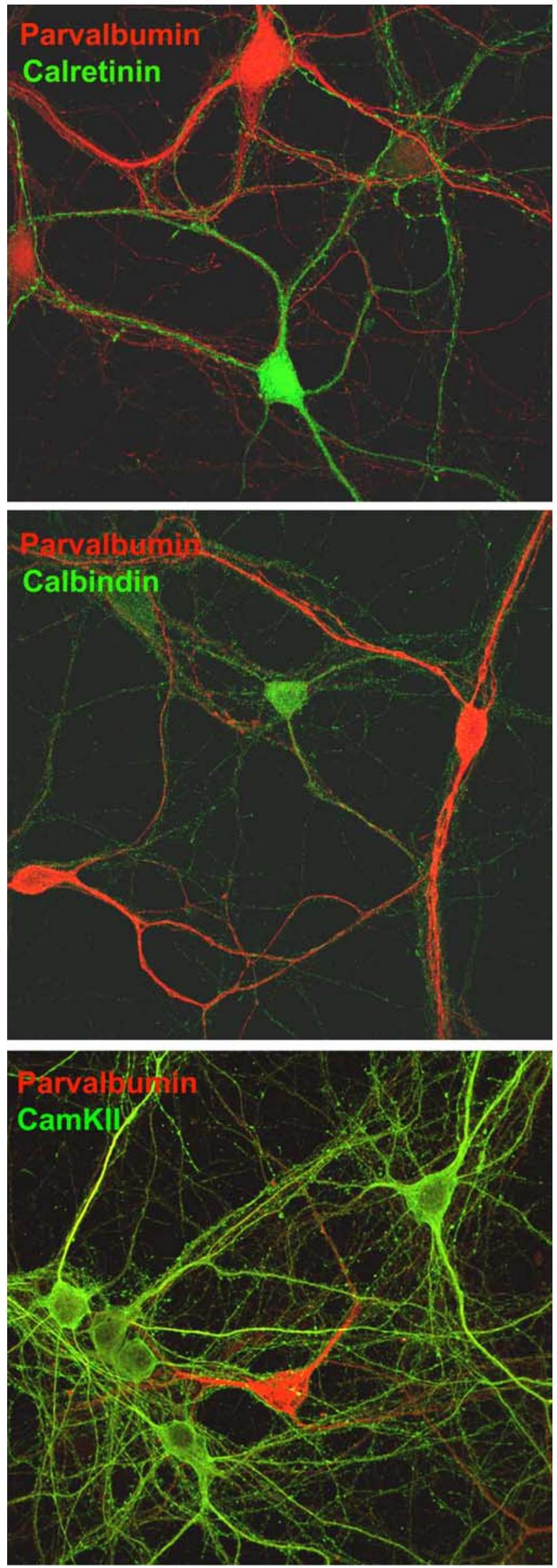

nocytochemistry using anti-PV and anti-GAD67 antibodies), and increasing thereafter reaching a plateau at approximately DIV20, when they reached $\sim 50 \%$ of the GABAergic population (Fig. 2). These results suggest that the development of the characteristic current pattern, as well as the activity-dependent regulation of the expression of the calcium-binding protein parvalbumin that were demonstrated in vivo also occurs in the cortical culture system. Furthermore, as described in slices (Cauli et al., 1997; Sik et al., 1998; Gulyas et al., 1999), PV interneurons in culture expressed high levels of the metabotropic glutamate receptor 5 and low levels of the ionotropic glutamate receptor subunit GluR2 (data not shown).

Expression of NMDA receptors in PV interneurons in culture Single-cell RT-PCR analysis performed with the subset of PVpositive fast spiking interneurons from rat cortical slices showed the presence of mRNAs for NR1, NR2A, NR2B, and NR2D in the majority of the population (Cauli et al., 1997). Moreover, localized NMDA-mediated calcium transients were recently demonstrated in these neurons (Goldberg et al., 2003). We analyzed the expression of the NR2A and NR2B subunits of the NMDA receptor at the protein level by immunocytochemistry, as well as at the mRNA level by linear amplification of mRNA content of single neurons, and compared it to the expression of these subunits in pyramidal neurons. Double-immunocytochemistry experiments using antibodies against PV or $\alpha$ CaMKII and antibodies against either NR2A or NR2B showed an apparently higher expression of NR2A than NR2B subunits in PV interneurons (Fig. $3 A, B$ ), differing from results obtained for pyramidal neurons at this developmental age (Fig. 3C,D). To confirm the high expression level for NR2A subunits found by immunocytochemistry in PV interneurons (Fig. 3A), we determined the mRNA concentrations for each NMDA receptor subunit at the single-interneuron level and compared these with the levels obtained for single pyramidal neurons. Coverslips containing neuronal cultures were allowed to develop for $21 \mathrm{~d}$ and fixed in $4 \%$ paraformaldehyde as for fluorescence immunocytochemistry. To label PV interneurons and pyramidal neurons, sister coverslips were stained for either PV or $\alpha$ CaMKII, respectively, and color-developed using Vectastain-DAB. The coverslips were then treated with formamide for single-cell mRNA amplification following standard protocols (see Materials and Methods) (Kacharmina et al., 1999). The cDNAs obtained after T7-RNA amplification were used for quantitative PCR for PV, $\alpha$ CaMKII, NR2A, NR2B, and GAPDH. Three pools of five cells of each type were analyzed for NR2A and NR2B transcript levels and normalized for their GAPDH mRNA content. Consistent with the immunocytochemical data and what has been reported for this developmental age (Williams et al., 1993; Molinoff et al., 1994; Sheng et al., 1994; Zhong et al., 1994, 1995), the ratio of NR2A/NR2B obtained for pyramidal neurons showed a slightly higher level for NR2B over NR2A mRNAs (ratio $2 \mathrm{~A} / 2 \mathrm{~B}, 0.84 \pm 0.22$ ). However, the ratio of NR2A/ NR2B obtained for PV interneurons showed a substantially higher level for NR2A than NR2B mRNA $(2 \mathrm{~A} / 2 \mathrm{~B}, 4.3 \pm 1.6)$, confirming the immunocytochemistry results.

$\leftarrow$

Figure 1. Cultured cortical interneurons represent a nonoverlapping population with respect to the expression of calcium-binding proteins. Dissociated cortical neurons were grown for $21 \mathrm{~d}$ in vitro and fixed in 4\% paraformaldehyde. Double immunocytochemistry was performed using a rabbit polyclonal antibody against PV (red) and a mouse monoclonal antibody (green) against calretinin (top), calbindin (middle), or $\alpha$ CaMKII (bottom) and AlexaFluorconjugated secondary antibodies. Scale bar, $15 \mu \mathrm{m}$. 
A

\section{Pyramidal neuron RSNP-neuron}
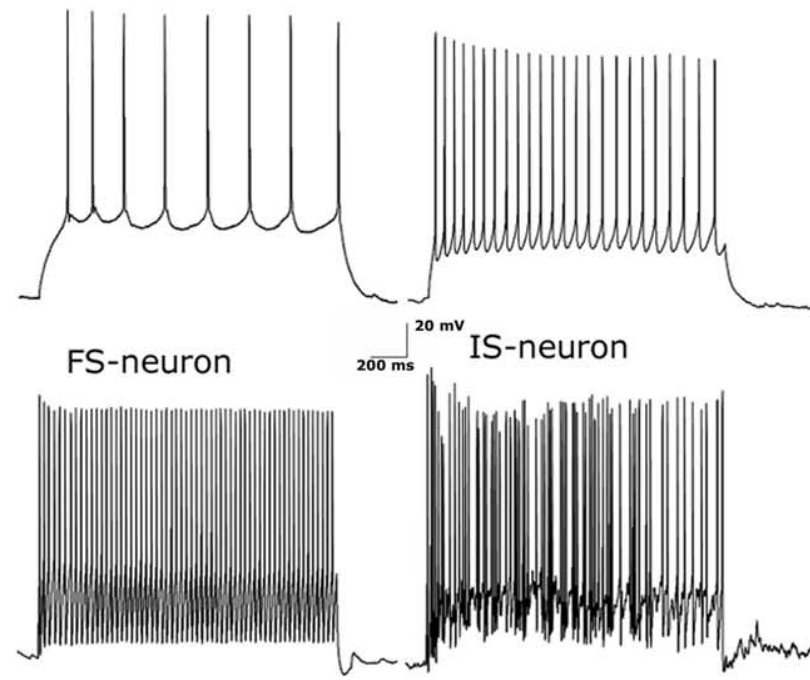

B

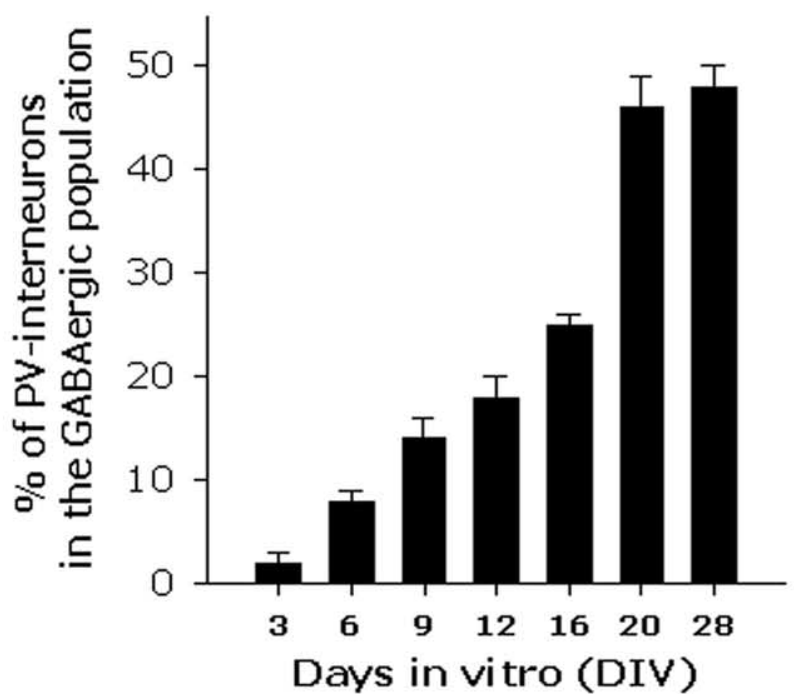

Figure 2. $\quad$ PV interneurons in culture develop a mature phenotype. $A$, Electrophysiological analysis revealed four firing patterns in response to depolarizing current injection in cortical neuronal cultures (DIV21-22). Neurons were depolarized by current steps of $100-250 \mathrm{pA}$ from a holding membrane potential of $-75 \mathrm{mV}$, adjusted to this value by continuous hyperpolarizing current injection. As was described for cortical slices (Cauli et al., 1997), we found the following current patterns in culture: regular spiking displaying frequency accommodation, corresponding to pyramidal neurons; regular-spiking nonpyramidal (RSNP-neuron); fastspiking without accommodation (FS-neuron); and an irregular-spiking (IS-neuron). B, Cortical neuronal cultures were fixed at the times indicated during development in vitro and analyzed for the expression of PV and GAD67 by double immunocytochemistry for quantification of the number of PV-positive interneurons in the GABAergic population. Error bars represent mean \pm SEM, obtained from three independent experiments for each time point. Ten fields obtained with a $40 \times$ objective were analyzed on each coverslip. The total number of neurons, GAD67positive, PV-positive, and double-labeled neurons were quantified ( $n=\sim 400$ neurons per condition) in each field.

Stimulation of NMDA receptors in PV interneurons induces the phosphorylation of ERK ${ }^{\text {MAPK }}$ and CREB

In pyramidal neurons, postsynaptic forms of plasticity are dependent on NMDA-mediated $\mathrm{Ca}^{2+}$ influx. This influx leads to the activation of several signaling cascades that transduce the initial $\mathrm{Ca}^{2+}$ rise into short- and long-term effects, such as activation of CaMKII and phosphorylation of the transcription factor CREB (for review, see Kennedy et al., 2005). However, little is known about the signaling cascades activated by the NMDA type of glutamate receptors in PV interneurons.

We analyzed the effects of a brief exposure to nontoxic NMDA concentrations on the activation of the ERK ${ }^{\mathrm{MAPK}}$ and the transcription factor CREB in PV interneurons to determine whether activation of NMDA receptors in these interneurons has longterm effects beyond the brief $\mathrm{Ca}^{2+}$ transients described previously (Goldberg et al., 2003). Dissociated cortical neurons developed for DIV21 were exposed to NMDA $(20 \mu \mathrm{M})$ in the absence or presence of the nonselective antagonist MK-801 $(5 \mu \mathrm{M})$, the NR2A-selective antagonist NVP-AAM077 $(0.5 \mu \mathrm{M})$ (Auberson et al., 2002; Berberich et al., 2005), or the NR2B-selective antagonist Ro-25-6981 (0.5 $\mu \mathrm{M})$ (Fischer et al., 1997). The cultures were fixed in $4 \%$ paraformaldehyde after either 15 min of NMDA exposure (when analyzing ERK1/2 phosphorylation) (Fig. 4A, left bar graph) or after 30 min of NMDA exposure (when analyzing CREB phosphorylation) (Fig. $4 \mathrm{~B}$, right bar graph). NMDA exposures produced a significant increase in the phosphorylation of ERK1/2 in the processes of PV interneurons, as analyzed by the use of phospho-specific antibodies (Fig. 4A, left bar graph). The increase in ERK1/2 phosphorylation was attenuated by the nonselective antagonist MK-801 and by the NR2A-selective antagonist NVP-AAM077 but not by the NR2B-selective antagonist Ro25-6981 (Fig. 4, left bar graph). The postsynaptic localization of the activation of ERK ${ }^{\mathrm{MAPK}}$ was confirmed by colocalization of the phospho-ERK1/2 staining with the interneuronal postsynaptic-protein citron (Fig. 4A, enlargement). We also observed an increase in the phosphorylation of the transcription factor CREB after 30 min of exposure to NMDA in PV interneurons (Fig. $4 B$, right bar graph), which was blocked by coexposure with the nonselective antagonist MK-801 and the NR2A-selective antagonist. The NR2B-selective antagonist only partially prevented the increase in CREB phosphorylation (Fig. 4, right bar graph).

NMDA receptor antagonists selectively reduce GAD67 and PV immunoreactivity in the PV subpopulation of interneurons in culture

The apparent mature phenotype of PV interneurons in culture, together with their expression of functional NMDA receptors, prompted us to analyze the effects of prolonged exposure to NMDA receptor antagonists on the expression of PV and GAD67, as a cellular correlate for in vivo results showing a decrease in parvalbumin expression after repetitive exposure to PCP (Cochran et al., 2002). Treatment of cortical cultures with the PCP-related compound ketamine produced a concentrationdependent reduction in GAD67 and PV in the PV interneuronal population as seen by immunostaining using specific antibodies for these markers (Fig. 5A) ([ketamine] $=0.00,0.01,0.10,0.50$ $\mu \mathrm{M})$. The decrease in GAD67 immunoreactivity was more rapid than the decline in PV immunoreactivity $\left(t_{1 / 2 \mathrm{Parv}}=\sim 8 \mathrm{~h}\right.$; $t_{1 / 2 \mathrm{GAD} 67}=\sim 4 \mathrm{~h}$ ) (Fig. $\left.5 B, C\right)$. We did not observe increased neuronal death after ketamine exposure up to $2 \mu \mathrm{M}$, as analyzed by Trypan blue exclusion (data not shown), propidium iodide staining (control, $10 \pm 2.2 \%$; ketamine, $8 \pm 1.2 \%$ ), percentage of cells presenting caspase- 3 activation (control, $8.5 \pm 0.5 \%$; ketamine, $7.0 \pm 0.7 \%$ ), or percentage of PV interneurons (control, $7.1 \pm 0.6 \%$; ketamine, $7.3 \pm 0.9 \%$ ).

Given the higher NR2A expression level in PV interneurons demonstrated above, we analyzed the role that the different NR2 
A

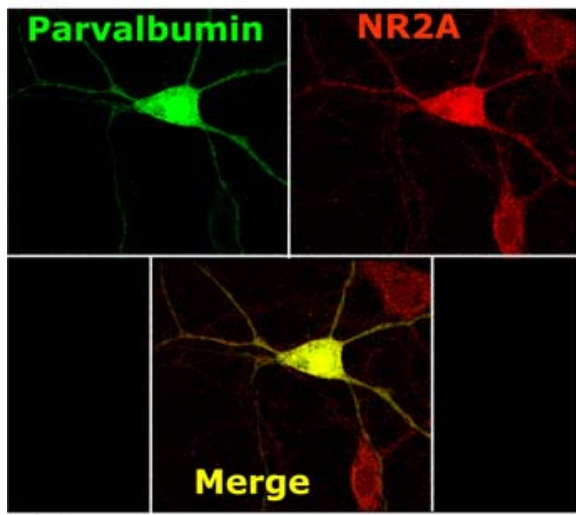

C

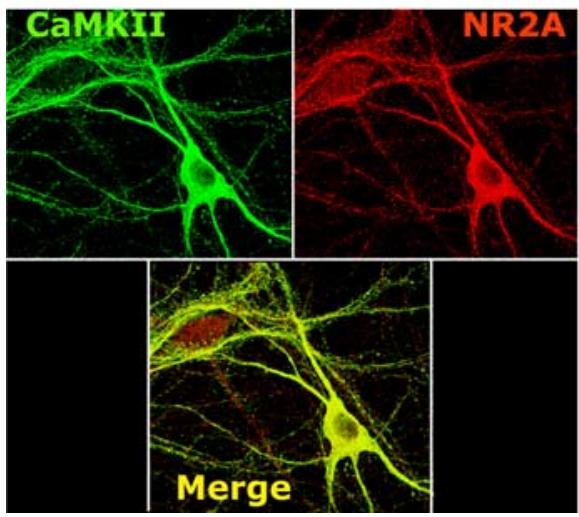

B

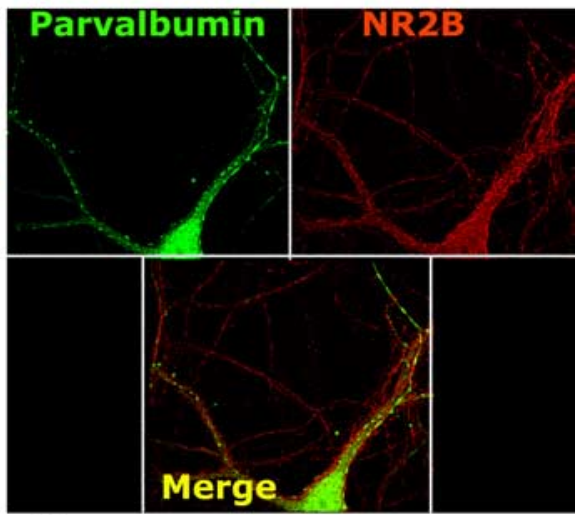

D

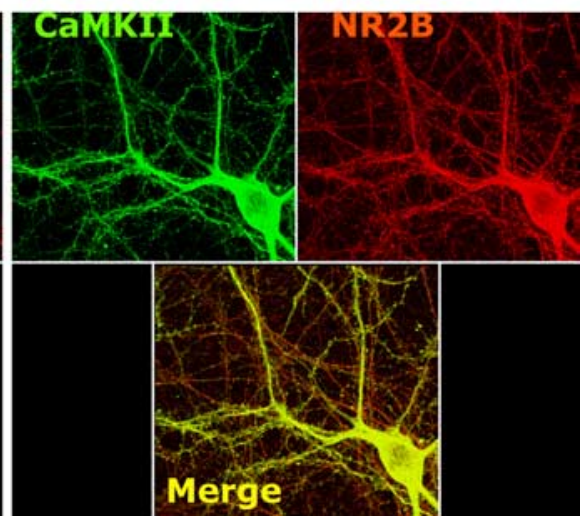

Figure 3. PV interneurons express higher levels of NR2A subunits compared with pyramidal neurons. DIV21 dissociated cortical neurons were fixed in 4\% paraformaldehyde and processed for double immunocytochemistry using antibodies directed to NR2A or NR2B and PV ( $\boldsymbol{A}$ and $\boldsymbol{B}$, respectively) and NR2A or NR2B and $\alpha$ CaMKII ( $\boldsymbol{C}$ and $\boldsymbol{D}$, respectively) using AlexaFluor-conjugated secondary antibodies.

(A and B) subunits may play in the NMDA receptor antagonistmediated loss of GAD67 and PV immunoreactivity. Exposure to increasing concentrations of NVP-AAM077 for $24 \mathrm{~h}$ reproduced the decrease in GAD67 and PV immunoreactivity observed when treating with ketamine (Fig. 6). The NR2B antagonist Ro-256981 partially reproduced the ketamine-mediated decrease in GAD67 (Fig. 6, bottom) but did not affect PV immunoreactivity (Fig. 6, top). The reduction in GAD67 induced by the NMDA receptor antagonists was restricted to the PV interneuronal population (Fig. 7A), and the decrease in PV and GAD67 immunoreactivity was reversed by a $24 \mathrm{~h}$ washout of the NMDA receptor antagonists (percentages of control after $24 \mathrm{~h}$ washout: GAD67, ketamine, $80 \pm$ 5.4\%; NVP-AAM077, $85 \pm$ 6.0\%; Ro-25-6981, $95 \pm 5 \%$; PV, ketamine, $90 \pm 5.4 \%$; NVP-AAM077, $96 \pm 4.2 \%$; R0-25-6981, $110 \pm 8.0 \%)$. Neither NVP-AAM077 nor Ro-256981 induced neuronal death under these conditions (data not shown).

Subchronic exposure to PCP was shown to reduce the level of PV mRNA in rat prefrontal cortex, and a similar dose of PCP was shown to produce a specific deficit in the extradimensional shift in an attentional set-shift task that corresponded to deficits seen in schizophrenic patients (Cochran et al., 2002; Egerton et al., 2005). Thus, the decrease in PV and GAD67 immunoreactivity observed in our culture system after $24 \mathrm{~h}$ NMDA antagonist exposures could be produced by a decrease in the mRNAs coding for these proteins. We studied this possibility by quantitative PCR in total mRNA obtained from cultures treated for $24 \mathrm{~h}$ in the absence or presence of $0.5 \mu \mathrm{M}$ ketamine, NVP-AAM077, or Ro-25-6981. No change in mRNA levels for either GAD67 or PV were observed after the $24 \mathrm{~h}$ treatments (Fig. $7 B$ ), suggesting that the loss in immunoreactivity is probably caused by selective protein degradation.

Increasing intracellular $\mathrm{Ca}^{2+}$ attenuates the NMDA -receptor antagonistmediated loss of GAD67 and PV immunoreactivity in cortical PV interneurons

When present in cortical interneurons, calcium-binding proteins are assumed to play a role in maintaining calcium homeostasis and to modulate neuronal excitability and resistance to biochemical damage. Parvalbumin, which displays a slow binding and dissociation rate for $\mathrm{Ca}^{2+}$, has been proposed to act as a slow calcium buffer regulating intracellular calcium homeostasis (Lee et al., 2000) and to be involved in the regulation of presynaptic calcium signaling and neurotransmitter release (Collin et al., 2005). Calcium homeostasis may be particularly important in PV interneurons, and calcium entering through NMDA and calcium-permeable AMPA receptors may play a fundamental role in the synaptic activation of these interneurons (Goldberg et al., 2003). We considered the possibility that, as a consequence of NMDA receptor blockade, a pronounced drop in intracellular calcium is produced that in turn induces, as a compensatory mechanism, the degradation of GAD67 followed by PV degradation. If so, increasing intracellular calcium should prevent the decrease in GAD67 and PV immunoreactivity caused by the NMDA antagonists. NMDA receptor antagonist treatment in the presence of the calcium channel opener BayK (5-10 $\mu \mathrm{M})$ (Fig. 8 ) or the PLC-coupled group I metabotropic glutamate receptor agonist DHPG (50 $\mu \mathrm{M})$ (Fig. 9), known to be linked to calcium release from intracellular stores, significantly attenuated the NMDA antagonist-mediated decrease in PV and GAD67 immunoreactivity in PV interneurons.

\section{Discussion}

Cortical neuronal cultures give rise to synaptic activity when developed in vitro (Dichter, 1978, 1980; Lesuisse and Martin, 2002; Kato-Negishi et al., 2004). Spontaneous inward currents driven by AMPA-type glutamate receptors were observed in these cultures as early as $10 \mathrm{~d}$ in vitro (Zona et al., 1994), and expression of inhibitory $\mathrm{GABA}_{\mathrm{A}}$ receptors was observed after 2 weeks in culture (Muir et al., 1996; Jovanovic et al., 2004). This type of cortical culture is widely used for studies of neurodegeneration, excitotoxicity, regulation of ion-channel activity, and neurotrophin or neurotransmitter intracellular signaling (Dugan et al., 1995; Behrens et al., 1999a,b; Yu et al., 2001; Heidinger et al., 2002; Jovanovic et al., 2004; Kim et al., 2005). We found that PV interneurons in culture express functional NMDA receptors, and that exposure to NMDA antagonists leads to a reversible loss of parvalbumin and GAD67 immunoreactivity in PV-GABAergic inter- 

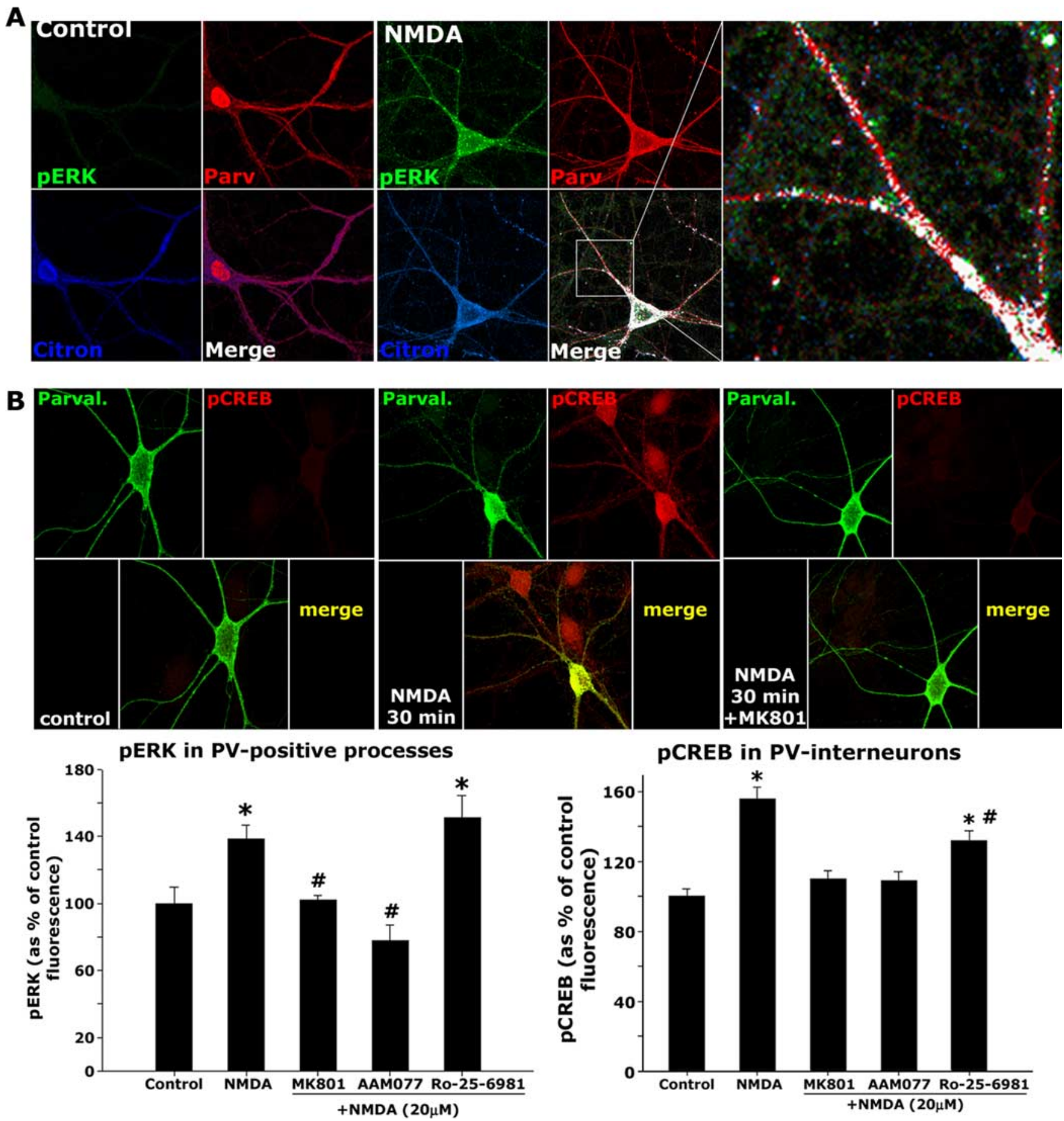

Figure 4. NMDA exposure triggers the phosphorylation of ERK ${ }^{\text {MAPK }}$ and CREB in PV interneurons. $A$, Coverslips containing DIV21 dissociated cortical neurons were washed in HCSS and exposed to $20 \mu \mathrm{m} \mathrm{NMDA}$ in the absence or presence of the NMDA receptor antagonists NVP-AAM077 $(0.5 \mu \mathrm{M})$, Ro-25-6981 $(0.5 \mu \mathrm{M})$, and MK-801 $(5 \mu \mathrm{m})$ for 15 min at $37^{\circ} \mathrm{C}$. Coverslips were immediately fixed in 4\% paraformaldehyde after treatments and processed for triple immunocytochemistry to detect PV (Parv; red), citron (blue), and phospho-ERK1/2 (pERK; green). Analysis of ERK phosphorylation was performed in the primary processes as depicted in the enlarged box at the right. The median fluorescence for each process was calculated and expressed as a percentage of the control fluorescence (no treatment; top left). All primary processes of $\sim 40$ cells per condition were analyzed across three independent experiments. The bar graph in $B$ (bottom left) depicts means \pm SEM. The asterisks indicate statistically significant with respect to control (ANOVA followed by Tukey's test; control vs NMDA, $F_{(1,190)}=107.03$; control vs Ro-25-6981, $\left.F_{(1,148)}=69.41\right)$. The number signs indicate statistically significant with respect to NMDA alone ( $p<0.05$ by ANOVA followed by Tukey's test; NMDA vs MK-801, $F_{(1,149)}=52.79 ;$ NMDA vs AAM077, $\left.F_{(1,141)}=135.23\right)$. $B$, Coverslips containing DIV21 dissociated cortical neurons were treated as in $\boldsymbol{A}$ for $30 \mathrm{~min}$ at $37^{\circ} \mathrm{C}$ and immediately fixed in $4 \%$ paraformaldehyde after treatments and processed for doubleimmunocytochemistry to detect PV (Parval.; green) and phospho-CREB (pCREB; red). Analysis of (REB phosphorylation was performed in the nuclear region of PV-positive neurons. The median fluorescence for each neuron was obtained and expressed as a percentage of the mean control fluorescence (no treatment; middle left). Approximately $40-60$ cells per condition were analyzed across three independent experiments. The bar graph (bottom right) depicts means \pm SEM. The asterisks indicate statistically significant with respect to control ( $p<0.05$ by ANOVA followed by Tukey's test; control vs NMDA, $F_{(1,60)}=50.21$; control vs Ro-25-6981, $F_{(1,52)}=21.87$ ). The number sign indicates statistically significant with respect to NMDA alone ( $p<0.05$ by ANOVA followed by Tukey's test; NMDA vs Ro-25-6981, $\left.F_{(1,54)}=7.18\right)$. 
A

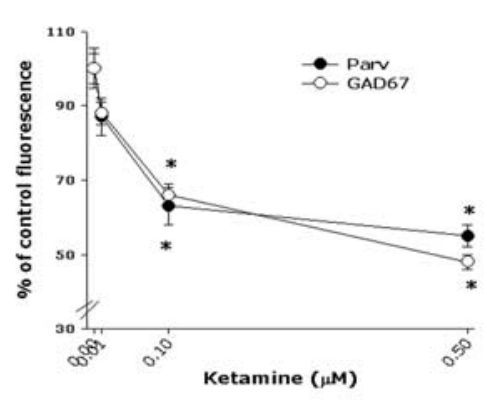

C
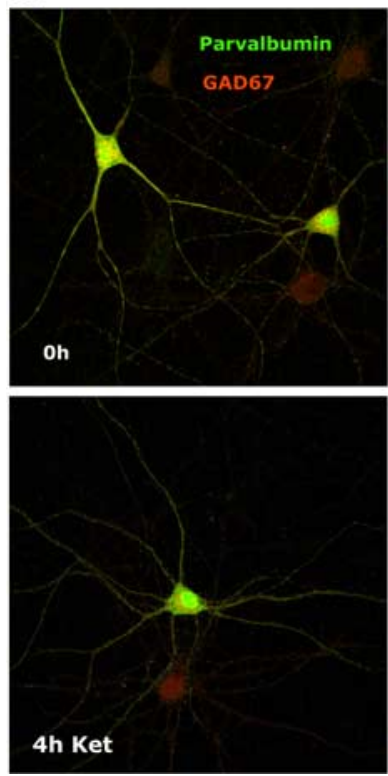

B

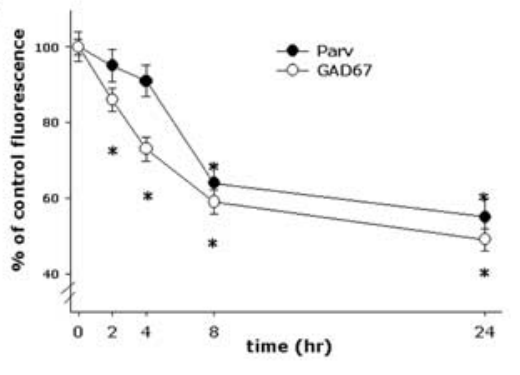

subunits represents that of the pyramidal cell population, which corresponds to the majority of the neurons in the culture system $(80-90 \%)$, and nothing is known about this switch in GABAergic interneurons.

PV interneurons in culture had an NMDA receptor subunit composition that differed from that found in the surrounding pyramidal neurons, with a much higher level of NR2A than NR2B present in PV interneurons. Stimulation of NMDA receptors in these interneurons lead to the activation of intracellular signaling pathways as was described in pyramidal neurons. NMDA induced the phosphorylation of the protein kinases ERK1/2 and the transcription factor CREB, suggesting that NMDA receptor activation in PV interneurons may have long-term transcriptional effects. However, the contribution of NR2A- and NR2B-containing receptors to the activation of these signaling pathways in PV interneurons was different from that observed in pyramidal neurons (Kim et al., 2005). Antagonizing NR2A-containing receptors blocked both ERK1/2 and CREB phosphorylation induced by NMDA in PV interneurons, whereas antagonizing NR2B-containing receptors only attenuated CREB phosphorylation. Nevertheless, it is our belief that the results obtained in pyramidal neurons should not be compared with what occurs in PV interneurons, because these neurons do not express the main transducer of the NMDA-mediated calcium signal present in pyramidal neurons, CaMKII, and less that half of the population of GABAergic interneurons express SynGAP (Zhang et al.,1999; our unpublished results), responsible for the regulation of the Ras-ERK pathway and substrate

neurons. Moreover, we showed that the loss of PV and GAD67 was dependent on NMDA receptors containing the NR2A subunit and was prevented by increasing intracellular calcium.

The GABAergic type of cortical interneurons corresponds to $10-20 \%$ of the neuronal population in the culture system. We show by immunostaining that this system gives rise to the three types of GABAergic interneurons known to be present in the adult cortical slice (i.e., calretinin-positive, calbindin-positive, and parvalbumin-positive) (Kawaguchi and Kubota, 1993; Cauli et al., 1997). The expression of parvalbumin in the PV-positive GABAergic population in culture followed a developmental pattern similar to that described in vivo and acquired the characteristic current patterns observed in slices (Cauli et al., 1997). Furthermore, the developmental switch in NR2-subunit mRNA found in vivo also occurs in the cultured system (Williams et al., 1993; Sheng et al., 1994; Zhong et al., 1994, 1995). We observed a similar change of these subunits in mouse primary cortical cultures at the protein level in either low-density dissociated cultures or high-density cortical neuronal-glial cocultures (our unpublished observations). However, this switch of NMDA receptor for CaMKII in pyramidal neurons (Kennedy et al., 2005).

A large contribution of NMDA receptors to subthreshold calcium signals and synaptic excitation was recently demonstrated in PV interneurons (Goldberg et al., 2003). We show here that when exposed to sublethal concentrations of ketamine, PV interneurons responded with a rapid loss of GAD67 and PV immunoreactivity, an effect reproduced by a NR2A-selective NMDA receptor antagonist, and less effectively by a NR2B-selective antagonist. This NMDA antagonist-mediated effect on PV and GAD67 expression was attenuated by increasing intracellular calcium either with a calcium channel opener (BayK) or through the activation of group I metabotropic glutamate receptors (DHPG). Given that PV interneurons express calcium-permeable AMPA receptors, which also contribute to synaptic calcium signals, our results support previous findings suggesting that NMDA receptors exert a tight control of intracellular calcium concentrations in these interneurons (Goldberg et al., 2003) and further indicate that decreases below a certain threshold induce the loss of their GABAergic phenotype. Because of the higher expression levels of NR2A subunits, most of NMDA receptors in these interneurons 

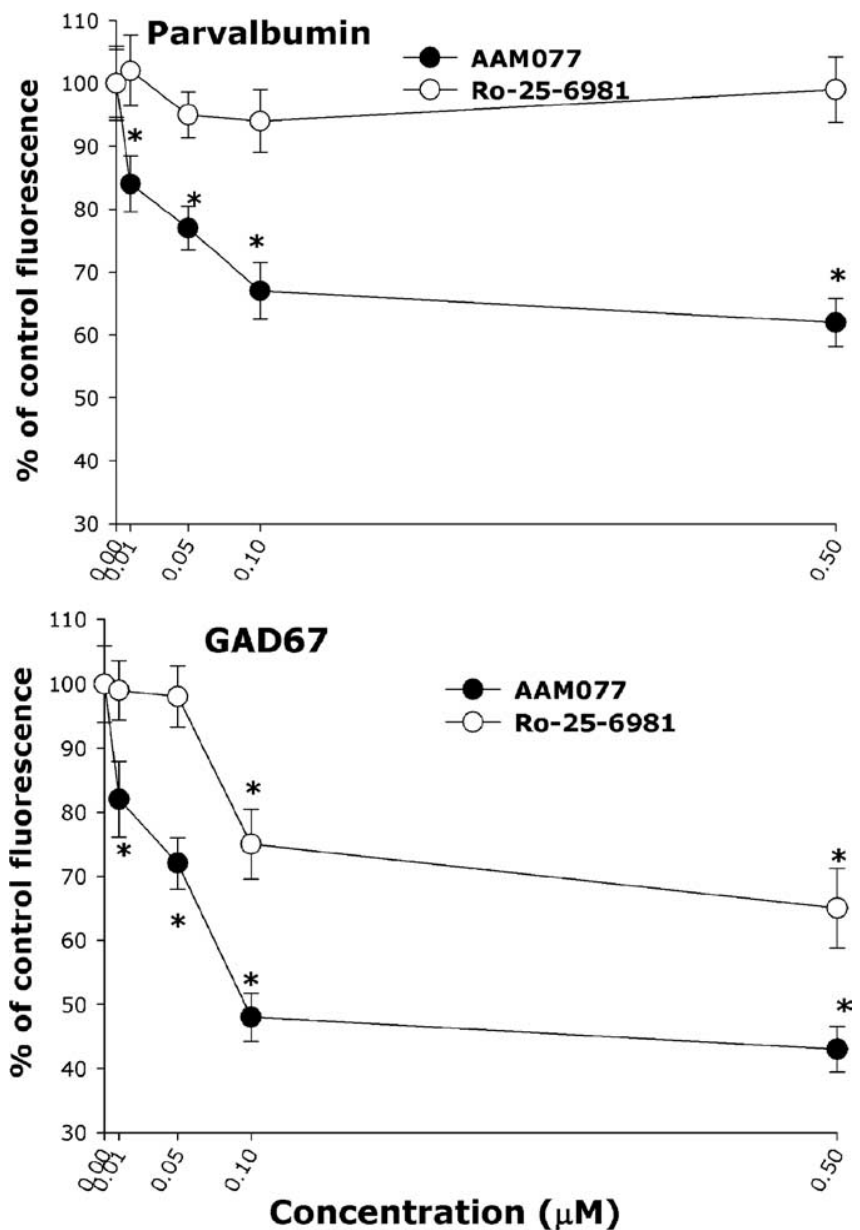

Figure 6. An NR2A-selective NMDA receptor antagonist reproduces ketamine effects in PV interneurons. DIV21 cortical neurons were exposed to varying concentrations of the NR2Aselective antagonist NVP-AAM077 (black circles) or the NR2B-selective antagonist Ro-25-6981 (red circles) for $24 \mathrm{~h}$ and processed for immunocytochemistry as in Figure 6. The NR2A-selective antagonist decreased the immunoreactivity for PV and GAD67 with an $\mathrm{EC}_{50}$ value of $\sim 50 \mathrm{~nm}$. The NR2B-selective antagonist only reduced GAD67 immunoreactivity with an $\mathrm{EC}_{50}$ value of $\sim 80 \mathrm{~nm}$. Forty to $60 \mathrm{PV}$ interneurons were analyzed per condition across four independent experiments. The asterisk indicates statistically significant with respect to control $(p<0.05$ by ANOVA followed by Tukey's test; dose-response multiple comparison for AAM077 GAD67, $F_{(5,248)}=41.17$; parvalbumin, $F_{(5,247)}=27.78$; time course multiple comparison for Ro-256981, GAD67, $F_{(5,258)}=16.55$; parvalbumin, $F_{(5,258)}=1.32$; no statistical difference, $p=$ $0.254)$.

will probably show the kinetics for receptors containing this subunit. Thus, it is possible to suggest a more important role for calcium entering through NR2A versus NR2B containing NMDA receptors in the control of the GABAergic phenotype of PV interneurons.

NMDA receptors are known to play an important role in the surface expression of AMPA receptors in pyramidal neurons (for review, see Bredt and Nicoll, 2003). It is possible to assume then that a prolonged blockade of NMDA receptors in these neurons would produce an overall decrease in excitatory synaptic transmission. This diminished glutamatergic transmission could then be responsible for the decrease in GAD67 and PV, independent of the function of NMDA receptors expressed by the interneurons. However, recent results have shown a differential role for NR2Aand NR2B-containing NMDA receptors in the surface expression of the GluR1 subunit of AMPA receptors, in which antagonizing
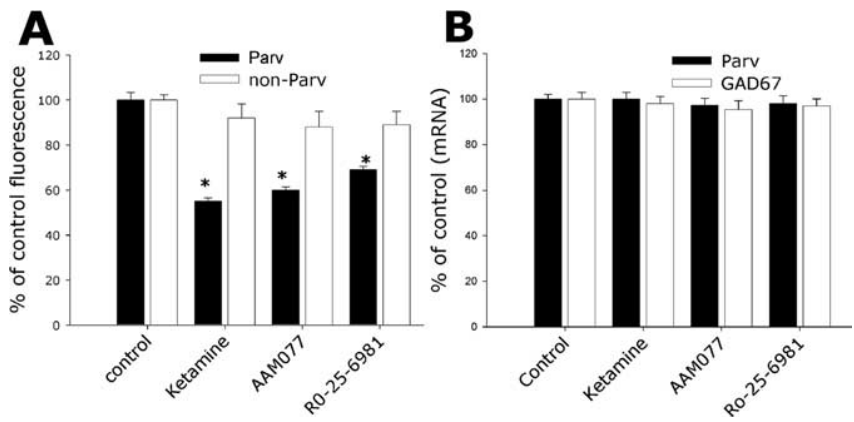

Figure 7. The decrease of GAD67 immunoreactivity was specific for PV interneurons and not accompanied by mRNA decrease. DIV21 cortical cultures were exposed to $0.5 \mu \mathrm{m}$ each of the NMDA receptor antagonists for $24 \mathrm{~h}$ and processed for immunocytochemistry as in Figure $6(\boldsymbol{A})$, or the whole content of the coverslip was collected for mRNA extraction followed by real-time PCR for GAD67 and PV mRNA quantification (B). Analysis of GAD67 immunoreactivity was performed in the PV (Parv) and non-PV (non-Parv) interneuronal population and expressed as a percentage of control conditions. A total of 100 non-PV and $60 \mathrm{PV}$ interneurons were analyzed across three independent experiments for each condition. The asterisks indicate statistically significant with respect to control conditions ( $p<0.05$ by ANOVA followed by Tukey's test multiple comparison procedures; $\left.F_{(3,281)}=101.83\right)$.

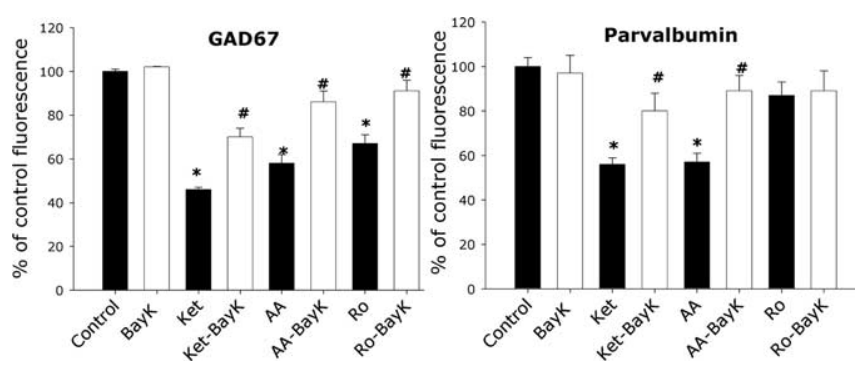

Figure 8. Increasing calcium influx attenuates the effects of NMDA receptor antagonists on GAD67 and PV immunoreactivity. DIV21 cortical neurons were exposed to $0.5 \mu \mathrm{m}$ concentrations of the indicated NMDA receptor antagonists in the presence or absence of the calcium channel opener BayK $(10 \mu \mathrm{M})$ for $24 \mathrm{~h}$ and processed for immunocytochemistry and fluorescence quantification of GAD67 and PV as in Figure 6. Sixty to 90 PV interneurons were analyzed per condition across three independent experiments. The asterisk indicates a statistical difference from control conditions ( $p<0.05$ by ANOVA followed by Tukey's test multiple comparison procedures $\operatorname{GAD67;} F_{(7,471)}=75.99 ;$ parvalbumin, $\left.F_{(7,446)}=38.22\right)$. The number sign indicates statistical difference from the same treatment in the absence of BayK $(p<0.05$ ANOVA followed by Tukey's test using the same multiple comparison procedures as for the asterisk).AA, AAM077; Ket, ketamine; Ro, Ro-25-6981 .

NR2B-containing receptors increased the surface expression of GluR1 in the presence of NMDA (Kim et al., 2005). This would be expected to increase, rather than decrease, glutamatergic transmission from principal neurons, and no effect on GAD67 or PV should be expected in the presence of an NR2B-selective antagonist. In contrast, we found that GAD67 immunoreactivity showed a statistically significant reduction after treatment with the NR2B-selective antagonist Ro-25-6981 (Fig. 6). We believe our results suggest that the effects observed after NMDA antagonist exposures are more related to the difference in expression levels for NR2A and B in PV interneurons and thus to their contribution to NMDA-mediated effects in the interneurons, rather than to the effects of the antagonists on principal neurons. Indeed, the NR2A subunit was shown to play an important role in the regulation of GABAergic inhibitory circuits in mice, and deletion of this NMDA receptor subunit 


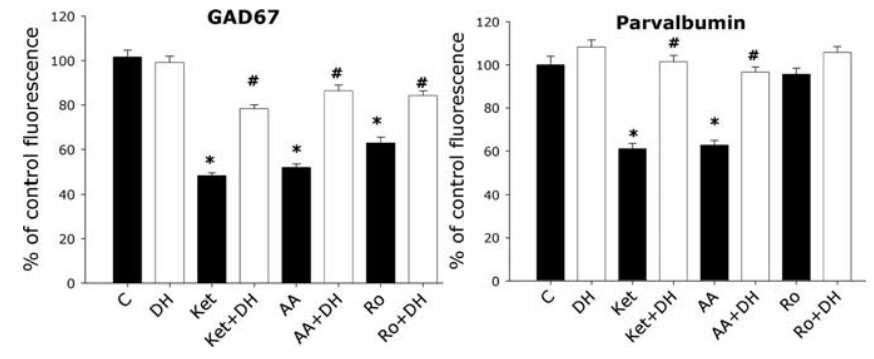

Figure 9. Activation of group I metabotropic glutamate receptors blocks the effect of the NMDA receptor antagonists on GAD67 and parvalbumin immunoreactivity. DIV21 cortical neuronal cultures were exposed to $0.5 \mu \mathrm{m}$ concentrations of the indicated NMDA receptor antagonists in the presence or absence of the group I metabotropic glutamate receptor agonist DHPG $(50 \mu \mathrm{M})$ for $24 \mathrm{~h}$ and processed for immunocytochemistry and fluorescence quantification of GAD67 and PV as in Figure 6. Sixty to 90 PV interneurons were analyzed per condition across three independent experiments. The asterisk indicates a statistical difference from control conditions ( $p<0.05$, ANOVA followed by Tukey's test multiple comparison procedures GAD67, $F_{(7,694)}=120.75$; parvalbumin, $\left.F_{(7,464)}=45.70\right)$. The number sign indicates statistical difference from the same treatment in the absence of DHPG ( $p<0.05$ by ANOVA followed by Tukey's test using the same multiple comparison procedures as for the asterisk). AA, AAM077; C, control; DH, DHPG; Ket, ketamine; Ro, Ro-25-6981.

conferred a hyperfunction of dopaminergic and serotoninergic systems, that was relieved by GABA receptor agonists and antipsychotics (Miyamoto et al., 2001). Furthermore, the presence of a microsatellite repeat in the promoter region of the NR2A gene in schizophrenics (Itokawa et al., 2003) and the decrease in the expression of NR2A subunits in GABAergic cells observed in schizophrenic subjects (Woo et al., 1997) may suggest a specific malfunction of NR2A-containing NMDA receptors in schizophrenia.

It has been postulated that the deficit in GAD67 mRNA expression observed in brain tissue of schizophrenic patients represents the response of the inhibitory system to a reduction in the glutamatergic excitatory drive (Akbarian et al., 1995; Olney et al., 1999). Our results showing that NMDA antagonists reduce GAD67 and parvalbumin immunoreactivity in cultured PV interneurons support this hypothesis at the protein level but not at the mRNA level. However, it is difficult to extrapolate from the culture system, in which PV interneurons only have the glutamatergic input from cortical pyramidal neurons, to the in vivo situation in which the brain circuitry remains intact. It is possible that a chronic hypoglutamatergic condition at the level of the corticolimbo-thalamic circuitry, created by repetitive exposure to PCP or ketamine, reflects the long-term effects of a diminished excitatory drive on the phenotypic characteristics of these interneurons, as proposed recently (Morris et al., 2005). Our results would thus reflect the acute propsychotic effects of NMDA antagonists, in which a direct role for NMDA receptors, specifically NR2A-containing, may be responsible for the maintenance of proper protein levels of GAD67 and parvalbumin in PV interneurons.

The protective effects of DHPG in the NMDA antagonistinduced GAD67 decrease are interesting, because PV interneurons express high levels of only one of the members of group I metabotropic glutamate receptors [i.e., mGluR5, both at the mRNA level (van Hooft et al., 2000) and at the protein level (our unpublished results)]. Interestingly, mGluR5 antagonists were shown to increase PCP and MK-801 effects on prepulse inhibition and locomotor activity (Henry et al., 2002; Pietraszek et al., 2005). Thus, strategies directed toward a selective activation of
mGluR5 could prove beneficial in the treatment of acute psychotic episodes caused by drugs acting as blockers of NMDA receptors.

In summary, we believe that a detailed study of the NMDAmediated signaling in PV interneurons in culture may help to elucidate the mechanisms behind the rapid disappearance of GAD67 and PV immunoreactivity caused by NMDA receptor antagonists and may suggest ways to prevent the loss of the GABAergic phenotype of these interneurons in schizophrenia.

\section{References}

Akbarian S, Kim JJ, Potkin SG, Hagman JO, Tafazzoli A, Bunney Jr WE, Jones EG (1995) Gene expression for glutamic acid decarboxylase is reduced without loss of neurons in prefrontal cortex of schizophrenics. Arch Gen Psychiatry 52:258-266.

Asada H, Kawamura Y, Maruyama K, Kume H, Ding R, Ji FY, Kanbara N, Kuzume H, Sanbo M, Yagi T, Obata K (1996) Mice lacking the $65 \mathrm{kDa}$ isoform of glutamic acid decarboxylase (GAD65) maintain normal levels of GAD67 and GABA in their brains but are susceptible to seizures. Biochem Biophys Res Commun 229:891-895.

Auberson YP, Allgeier H, Bischoff S, Lingenhoehl K, Moretti R, Schmutz M (2002) 5-Phosphonomethylquinoxalinediones as competitive NMDA receptor antagonists with a preference for the human 1A/2A, rather than $1 \mathrm{~A} / 2 \mathrm{~B}$ receptor composition. Bioorg Med Chem Lett 12:1099-1102.

Barraud P, Thompson L, Kirik D, Bjorklund A, Parmar M (2005) Isolation and characterization of neural precursor cells from the Sox1-GFP reporter mouse. Eur J Neurosci 22:1555-1569.

Behrens MM, Strasser U, Koh JY, Gwag BJ, Choi DW (1999a) Prevention of neuronal apoptosis by phorbol ester-induced activation of protein kinase C: blockade of p38 mitogen-activated protein kinase. Neuroscience 94:917-927.

Behrens MM, Strasser U, Heidinger V, Lobner D, Yu SP, McDonald JW, Won M, Choi DW (1999b) Selective activation of group II mGluRs with LY354740 does not prevent neuronal excitotoxicity. Neuropharmacology 38:1621-1630.

Berberich S, Punnakkal P, Jensen V, Pawlak V, Seeburg PH, Hvalby O, Kohr G (2005) Lack of NMDA receptor subtype selectivity for hippocampal long-term potentiation. J Neurosci 25:6907-6910.

Bredt DS, Nicoll RA (2003) AMPA receptor trafficking at excitatory synapses. Neuron 40:361-379.

Cauli B, Audinat E, Lambolez B, Angulo MC, Ropert N, Tsuzuki K, Hestrin S, Rossier J (1997) Molecular and physiological diversity of cortical nonpyramidal cells. J Neurosci 17:3894-3906.

Cochran SM, Fujimura M, Morris BJ, Pratt JA (2002) Acute and delayed effects of phencyclidine upon mRNA levels of markers of glutamatergic and GABAergic neurotransmitter function in the rat brain. Synapse 46:206-214.

Cochran SM, Kennedy M, McKerchar CE, Steward LJ, Pratt JA, Morris BJ (2003) Induction of metabolic hypofunction and neurochemical deficits after chronic intermittent exposure to phencyclidine: differential modulation by antipsychotic drugs. Neuropsychopharmacology 28:265-275.

Collin T, Chat M, Lucas MG, Moreno H, Racay P, Schwaller B, Marty A, Llano I (2005) Developmental changes in parvalbumin regulate presynaptic $\mathrm{Ca}^{2+}$ signaling. J Neurosci 25:96-107.

de Lecea L, del Rio JA, Soriano E (1995) Developmental expression of parvalbumin mRNA in the cerebral cortex and hippocampus of the rat. Brain Res Mol Brain Res 32:1-13.

Dichter MA (1978) Rat cortical neurons in cell culture: culture methods, cell morphology, electrophysiology, and synapse formation. Brain Res 149:279-293.

Dichter MA (1980) Physiological identification of GABA as the inhibitory transmitter for mammalian cortical neurons in cell culture. Brain Res 190:111-121.

Dugan LL, Bruno VMG, Amagasu SM, Giffard RG (1995) Glia modulate the response of murine cortical neurons to excitotoxicity: glia exacerbate AMPA neurotoxicity. J Neurosci 15:4545-4555.

Egerton A, Reid L, McKerchar CE, Morris BJ, Pratt JA (2005) Impairment in 
perceptual attentional set-shifting following PCP administration: a rodent model of set-shifting deficits in schizophrenia. Psychopharmacology (Berl) 179:77-84.

Erickson SL, Lewis DA (2002) Postnatal development of parvalbumin- and GABA transporter-immunoreactive axon terminals in monkey prefrontal cortex. J Comp Neurol 448:186-202.

Fischer G, Mutel V, Trube G, Malherbe P, Kew JN, Mohacsi E, Heitz MP, Kemp JA (1997) Ro 25-6981, a highly potent and selective blocker of $\mathrm{N}$-methyl-D-aspartate receptors containing the NR2B subunit. Characterization in vitro. J Pharmacol Exp Ther 283:1285-1292.

Francis N, Deneris ES (2002) Retinal neuron activity of ETS domainbinding sites in a nicotinic acetylcholine receptor gene cluster enhancer. J Biol Chem 277:6511-6519.

Freund TF (2003) Interneuron diversity series: rhythm and mood in perisomatic inhibition. Trends Neurosci 26:489-495.

Goldberg JH, Yuste R, Tamas G (2003) $\mathrm{Ca}^{2+}$ imaging of mouse neocortical interneurone dendrites: contribution of $\mathrm{Ca}^{2+}$-permeable AMPA and NMDA receptors to subthreshold $\mathrm{Ca}^{2+}$ dynamics. J Physiol (Lond) 551:67-78.

Goslin K, Asmussen H, Banker G (1998) Rat hippocampal neurons in lowdensity culture. In: Culturing nerve cells, Ed 2 (Banker G, Goslin K, eds), pp 339-370. London: MIT.

Gottron FJ, Ying HS, Choi DW (1997) Caspase inhibition selectively reduces the apoptotic component of oxygen-glucose deprivation-induced cortical neuronal cell death. Mol Cell Neurosci 9:159-169.

Gulyas AI, Megias M, Emri Z, Freund TF (1999) Total number and ratio of excitatory and inhibitory synapses converging onto single interneurons of different types in the CAl area of the rat hippocampus. J Neurosci 19:10082-10097.

Hashimoto T, Volk DW, Eggan SM, Mirnics K, Pierri JN, Sun Z, Sampson AR, Lewis DA (2003) Gene expression deficits in a subclass of GABA neurons in the prefrontal cortex of subjects with schizophrenia. J Neurosci 23:6315-6326.

Heidinger V, Manzerra P, Wang XQ, Strasser U, Yu SP, Choi DW, Behrens MM (2002) Metabotropic glutamate receptor 1-induced upregulation of NMDA receptor current: mediation through the Pyk2/Src-family kinase pathway in cortical neurons. J Neurosci 22:5452-5461.

Henry SA, Lehmann-Masten V, Gasparini F, Geyer MA, Markou A (2002) The mGluR5 antagonist MPEP, but not the mGluR2/3 agonist LY314582, augments PCP effects on prepulse inhibition and locomotor activity. Neuropharmacology 43:1199-1209.

Huang EJ, Liu W, Fritzsch B, Bianchi LM, Reichardt LF, Xiang M (2001) Brn3a is a transcriptional regulator of soma size, target field innervation and axon pathfinding of inner ear sensory neurons. Development 128:2421-2432.

Irintchev A, Rollenhagen A, Troncoso E, Kiss JZ, Schachner M (2005) Structural and functional aberrations in the cerebral cortex of tenascin- $\mathrm{C}$ deficient mice. Cereb Cortex 15:950-962.

Itokawa M, Yamada K, Yoshitsugu K, Toyota T, Suga T, Ohba H, Watanabe A, Hattori E, Shimizu H, Kumakura T, Ebihara M, Meerabux JM, Toru M, Yoshikawa T (2003) A microsatellite repeat in the promoter of the $\mathrm{N}$-methyl-D-aspartate receptor 2A subunit (GRIN2A) gene suppresses transcriptional activity and correlates with chronic outcome in schizophrenia. Pharmacogenetics 13:271-278.

Javitt DC, Zukin SR (1991) Recent advances in the phencyclidine model of schizophrenia. Am J Psychiatry 148:1301-1308.

Jovanovic JN, Thomas P, Kittler JT, Smart TG, Moss SJ (2004) Brainderived neurotrophic factor modulates fast synaptic inhibition by regulating $\mathrm{GABA}_{\mathrm{A}}$ receptor phosphorylation, activity, and cell-surface stability. J Neurosci 24:522-530.

Kacharmina JE, Crino PB, Eberwine J (1999) Preparation of cDNA from single cells and subcellular regions. Methods Enzymol 303:3-18.

Kato-Negishi M, Muramoto K, Kawahara M, Kuroda Y, Ichikawa M (2004) Developmental changes of GABAergic synapses formed between primary cultured cortical neurons. Brain Res Dev Brain Res 152:99-108.

Kawaguchi Y, Kubota Y (1993) Correlation of physiological subgroupings of nonpyramidal cells with parvalbumin- and calbindinD28kimmunoreactive neurons in layer $\mathrm{V}$ of rat frontal cortex. J Neurophysiol 70:387-396.

Keilhoff G, Becker A, Grecksch G, Wolf G, Bernstein HG (2004) Re- peated application of ketamine to rats induces changes in the hippocampal expression of parvalbumin, neuronal nitric oxide synthase and cFOS similar to those found in human schizophrenia. Neuroscience 126:591-598.

Kennedy MB, Beale HC, Carlisle HJ, Washburn LR (2005) Integration of biochemical signalling in spines. Nat Rev Neurosci 6:423-434.

Kim MJ, Dunah AW, Wang YT, Sheng M (2005) Differential roles of NR2Aand NR2B-containing NMDA receptors in Ras-ERK signaling and AMPA receptor trafficking. Neuron 46:745-760.

Lee SH, Schwaller B, Neher E (2000) Kinetics of $\mathrm{Ca}^{2+}$ binding to parvalbumin in bovine chromaffin cells: implications for $\left[\mathrm{Ca}^{2+}\right]$ transients of neuronal dendrites. J Physiol (Lond) 525:419-432.

Lesuisse C, Martin LJ (2002) Long-term culture of mouse cortical neurons as a model for neuronal development, aging, and death. J Neurobiol 51:9-23.

Lewis DA, Hashimoto T, Volk DW (2005) Cortical inhibitory neurons and schizophrenia. Nat Rev Neurosci 6:312-324.

Mirnics K, Middleton FA, Marquez A, Lewis DA, Levitt P (2000) Molecular characterization of schizophrenia viewed by microarray analysis of gene expression in prefrontal cortex. Neuron 28:53-67.

Miyamoto Y, Yamada K, Noda Y, Mori H, Mishina M, Nabeshima T (2001) Hyperfunction of dopaminergic and serotonergic neuronal systems in mice lacking the NMDA receptor epsilon1 subunit. J Neurosci 21:750-757.

Molinoff PB, Williams K, Pritchett DB, Zhong J (1994) Molecular pharmacology of NMDA receptors: modulatory role of NR2 subunits. Prog Brain Res 100:39-45.

Monyer H, Burnashev N, Laurie DJ, Sakmann B, Seeburg PH (1994) Developmental and regional expression in the rat brain and functional properties of four NMDA receptors. Neuron 12:529-540.

Morris BJ, Cochran SM, Pratt JA (2005) PCP: from pharmacology to modelling schizophrenia. Curr Opin Pharmacol 5:101-106.

Muir JK, Lobner D, Monyer H, Choi DW (1996) GABA receptor activation attenuates excitotoxicity but exacerbates oxygen-glucose deprivation-induced neuronal injury in vitro. J Cereb Blood Flow Metab 16:1211-1218.

Newcomer JW, Krystal JH (2001) NMDA receptor regulation of memory and behavior in humans. Hippocampus 11:529-542.

Nyiri G, Stephenson FA, Freund TF, Somogyi P (2003) Large variability in synaptic $\mathrm{N}$-methyl-D-aspartate receptor density on interneurons and a comparison with pyramidal-cell spines in the rat hippocampus. Neuroscience 119:347-363.

Olney JW, Farber NB (1995) Glutamate receptor dysfunction and schizophrenia. Arch Gen Psychiatry 52:998-1007.

Olney JW, Newcomer JW, Farber NB (1999) NMDA receptor hypofunction model of schizophrenia. J Psychiatr Res 33:523-533.

Ouyang Y, Kantor D, Harris KM, Schuman EM, Kennedy MB (1997) Visualization of the distribution of autophosphorylated calcium/calmodulindependent protein kinase II after tetanic stimulation in the CA1 area of the hippocampus. J Neurosci 17:5416-5427.

Philpot BD, Lim JH, Brunjes PC (1997) Activity-dependent regulation of calcium-binding proteins in the developing rat olfactory bulb. J Comp Neurol 387:12-26.

Pietraszek M, Gravius A, Schafer D, Weil T, Trifanova D, Danysz W (2005) mGluR5, but not mGluR1, antagonist modifies MK-801-induced locomotor activity and deficit of prepulse inhibition. Neuropharmacology 49:73-85.

Reynolds GP, Zhang ZJ, Beasley CL (2001) Neurochemical correlates of cortical GABAergic deficits in schizophrenia: selective losses of calcium binding protein immunoreactivity. Brain Res Bull 55: 579-584.

Rose K, Goldberg M, Choi D (1993) Cytotoxicity in murine cortical cell culture. In: In vitro biological methods. Methods in toxicology (Tyson C, Frazier J, eds), pp 46-60. San Diego: Academic.

Sheng M, Cummings J, Roldan LA, Jan YN, Jan LY (1994) Changing subunit composition of heteromeric NMDA receptors during development of rat cortex. Nature 368:144-147.

Sik A, Hajos N, Gulacsi A, Mody I, Freund TF (1998) The absence of a major $\mathrm{Ca}^{2+}$ signaling pathway in GABAergic neurons of the hippocampus. Proc Natl Acad Sci USA 95:3245-3250. 
Snell LD, Nunley KR, Lickteig RL, Browning MD, Tabakoff B, Hoffman PL (1996) Regional and subunit specific changes in NMDA receptor mRNA and immunoreactivity in mouse brain following chronic ethanol ingestion. Brain Res Mol Brain Res 40:71-78.

Torrey EF, Barci BM, Webster MJ, Bartko JJ, Meador-Woodruff JH, Knable MB (2005) Neurochemical markers for schizophrenia, bipolar disorder, and major depression in postmortem brains. Biol Psychiatry $57: 252-260$.

van Hooft JA, Giuffrida R, Blatow M, Monyer H (2000) Differential expression of group I metabotropic glutamate receptors in functionally distinct hippocampal interneurons. J Neurosci 20:3544-3551.

Williams K, Russell SL, Shen YM, Molinoff PB (1993) Developmental switch in the expression of NMDA receptors occurs in vivo and in vitro. Neuron 10:267-278.

Woo TU, Miller JL, Lewis DA (1997) Schizophrenia and the parvalbumin- containing class of cortical local circuit neurons. Am J Psychiatry 154:1013-1015.

Yu SP, Canzoniero LM, Choi DW (2001) Ion homeostasis and apoptosis. Curr Opin Cell Biol 13:405-411.

Zhang W, Vazquez L, Apperson M, Kennedy MB (1999) Citron binds to PSD-95 at glutamatergic synapses on inhibitory neurons in the hippocampus. J Neurosci 19:96-108.

Zhong J, Russell SL, Pritchett DB, Molinoff PB, Williams K (1994) Expression of mRNAs encoding subunits of the $N$-methyl-D-aspartate receptor in cultured cortical neurons. Mol Pharmacol 45:846-853.

Zhong J, Carrozza DP, Williams K, Pritchett DB, Molinoff PB (1995) Expression of mRNAs encoding subunits of the NMDA receptor in developing rat brain. J Neurochem 64:531-539.

Zona C, Palma E, Brancati A, Avoli M (1994) Age-dependent appearance of synaptic currents in rat neocortical neurons in culture. Synapse 18:1-6. 